\title{
K POJMOVÉ NEJEDNOTNOSTI PORUŠENÍ ZABEZPEČENÍ/BEZPEČNOSTI OSOBNÍCH ÚDAJU゚ V ČESKÉM PRÁVU
}

\author{
FRANTIŠEK KASL*
}

\begin{abstract}
The Terminological Inconsistency of Personal Data Breach in the Czech Law
The contribution compares the terminology of current and previous Czech and European personal data protection law from the perspective of the use of two possible Czech terms for the personal data breach. Firstly, the pattern of the use of these legal terms is analysed with regard to the relevant legal framework and the difference or overlay of their normative content is assessed. The identified disparities within or between the core laws are assessed on the European level first based on the comparison of the language versions and then also in broader context. The conclusion of the contribution is a structured argumentation in favour of one of the terms.
\end{abstract}

Klíčová slova: porušení zabezpečení osobních údajů; porušení bezpečnosti osobních údajů; narušení bezpečnosti osobních údajů; obecné nařízení o ochraně osobních údajů

Keywords: personal data breach; GDPR

DOI: $10.14712 / 23366478.2019 .34$

\section{1. ÚVOD ${ }^{1}$}

Nový jednotný evropský právní rámec ochrany osobních údajů přinesl řadu změn a nových právních institutů. V rámci této komplexní novelizace nosných norem oboru lze však nalézt jisté změny, které se zdají býti neodůvodněné. Př́ikladem je užití pojmu zabezpečení osobních údajů na úkor předchozího termínu bezpečnost osobních údajů, preferovaného evropskou právní úpravou. Cílem tohoto prríspěvku je podrobněji nahlédnout na tuto terminologickou proměnu a zhodnotit, jaké možné praktické důsledky s sebou přináší a zda jde o změnu konzistentní z hlediska právně teoretického.

* Mgr. Ing. František Kasl je prezenčním doktorským studentem na Ústavu práva a technologií Právnické fakulty Masarykovy univerzity.

1 Tento článek byl zpracován za podpory Technologické agentury ČR v rámci projektu „Právní a technické prostředky pro ochranu soukromi v kyberprostoru (TL02000398)“. Závěry př́íspěvku byly prezentovány před odborným publikem na XIII. ročníku konference pro doktorandy a mladé právní vědce COFOLA 2019 uspořádané Právnickou fakultou Masarykovy univerzity dne 5. dubna 2019 v Telči. 


\section{INTERPRETACE PRÁVA}

Předpokladem řádného poznávání či aplikace obsahu právní normy je vhodné užití metod právní interpretace. Výkladové metody a př́ípustné argumentační postupy pro propojování textového znění právní normy s jejím právním významem jsou jádrem arzenálu právních profesí. Přes jisté dělení či systemizaci těchto metod není pevně stanovena jejich hierarchie, ale je zpravidla zdůrazňována potřeba jejich využití v kombinaci a jejich bilancování s ohledem na konkrétní situaci. ${ }^{2}$

Př́močará metoda výkladu právního textu je založena na nalézání jeho jazykového a gramatického významu. Je jí tedy předvídáno, že zákonodárce užívá slov s ohledem na jejich význam a užívá text normy co nejbližší jejímu významovému obsahu z právního hlediska. ${ }^{3}$ Tento předpoklad je doplňován o očekávání systematického a logického formulování právních norem, kdy lze následně při výkladu či poznávání obsahu referovat na ustálená systematická pravidla struktury právního předpisu a dovozovat záměr zákonodárce z postavení, řazení či kategorizace jednotlivých prvků v předpisu obsažených. ${ }^{4}$ Logický výklad následně odkazuje na předpoklad obecné racionality jednání a projevu zákonodárce, kdy lze při nejednoznačném či nevysloveném obsahovém komponentu normy využít standardních logických postupů $\mathrm{k}$ výkladu, který je $\mathrm{v}$ souladu se záměrem zákonodárce. ${ }^{5} \mathrm{Na}$ základě této trojice metod, některými autory označovaných jako standardní výkladové metody práva, ${ }^{6}$ je zpravidla možné učinit jednoznačné soudy týkající se hlavních obsahových kontur právní normy.

Vzhledem $\mathrm{k}$ abstraktnosti právně-normativní úpravy a neúměrné složitosti a různorodosti životních situací, na které je aplikována, je možné shledat potřebu pro využití dalších, doplňujících metod výkladu obsahu právní normy. Jde především o situace jazykové nejednotnosti, zjevné nesystematičnosti či logické neucelenosti určitých ustanovení v rámci normy či ve vztahu k normám ostatním. Právní teorie přijímá poznání, že jazyk není optimální nástroj pro vyjádření právních norem $v$ jejich úplnosti. Je tedy nutné nalézat účel a smysl právní normy stojící za daným jazykovým vyjádřením, ač tím může docházet k překonání závěrů na základě jazykového výkladu. ${ }^{7}$ Souvisejícím argumentem ve prospěch jisté nadřazenosti teleologického výkladu je pak překonání mýtu racionálního a neomylného zákonodárce a pragmatická akceptace často značně tristní reality soudobého legislativního procesu. Často je tedy nutné prohlédnout za vlastní text a systematiku právního předpisu a za pomoci doktrinální, historické či komparativní analýzy nalézat skutečný obsah, který je právní normou a měl by být textem vyjádřen, ač není.

\footnotetext{
MELZER, F. Metodologie nalézáni práva; Úvod do právní argumentace. Praha: C. H. Beck, 2010, s. 78. BOGUSZAK, J. - ČAPEK, J. - GERLOCH, A. Teorie práva. Praha: ASPI, 2003, s. 151.

MELZER, c. d., s. 130.

KNAPP, V. Teorie práva. Praha: C. H. Beck, 1995, s. 171.

BOGUSZAK - ČAPEK - GERLOCH, c. d., s. 156.

MELZER, c. d., s. 159.
} 


\section{PRÁVNÍ NORMY OCHRANY OSOBNÍCH ÚDAJU゚ A JEJICH VÝKLAD}

Obecný úvod $\mathrm{k}$ interpretaci práva $\mathrm{v}$ předchozích odstavcích nepřináší nové poznatky právně znalým čtenářům, je však pokladem pro následující proces poznávání práva ve vztahu ke konkrétní právní skutečnosti (porušení zabezpečení osobních údajů či narušeni/porušení bezpečnosti osobních údajů), resp. právem chráněné hodnoty ( $z a$ bezpečení zpracování osobních údajů či bezpečnost zpracování osobních údajů).

Problematika ochrany osobních údajů představuje z hlediska normotvorby značně dynamickou oblast, která postihuje velmi široké spektrum dílčích situací z pohledu značně abstraktních právních norem. Projevují se zde konflikty mezi veřejnoprávní a soukromoprávní povahou jednotlivých ustanovení př́islušných právních předpisů. Současně jde o oblast, pro kterou potřeba právní úpravy vychází z tlaku v důsledku změny společenské reality působené technologických pokrokem a digitalizací interakcí v moderní společnosti. Právní úprava zde tedy čelí neustálé potřebě „dohánět“ společenskou realitu. ${ }^{8}$ To činí text právních norem často nepřiléhavým a vede k potřebě extenzivního či analogického výkladu za účelem zachování funkce dané právní normy. ${ }^{9}$

V neposlední řadě pak jde o jeden z předních segmentů právní úpravy, ve kterých se prosadila sjednocující iniciativa legislativního projektu Evropské unie. Dochází zde tudíž v současné době ke střetu právních norem národního a nadnárodního zákonodárce. Ten přináší dodatečný metodologický prvek do výkladu obsahu právní normy, totiž požadavek eurokonformního výkladu. ${ }^{10}$ Je jím doplňován obecný požadavek na teleologický soulad s ústavní normou, může však mít i mnohem konkrétnější a výraznější dopad. ${ }^{11}$

\section{KDYŽ SE ŘEKNE „PERSONAL DATA BREACH“}

Předmětem tohoto pojednání je interpretační analýza jazykové nejednotnosti právních norem vztahujících se $\mathrm{k}$ jednomu z nosných prvků systematiky práva ochrany osobních údajů. Lze totiž dovozovat, že primárním účelem pravidel založených touto právní oblastí je vymezení prrípustného postupu pro nakládání s osobními údaji, který adekvátně respektuje práva a svobody dotčené fyzické osoby. ${ }^{12}$ Zásadní roli tudíž hrají požadavky a povinnosti vedoucí k zabránění či zmírnění důsledků situací, kdy dojde k porušení těchto mantinelů, at již subjektem, který jinak údaje nabyl a zpracovával v souladu s právní úpravou, či skrze nahodilý či cílený incident, který údaje zpř́stupnil třetí osobě, která $\mathrm{k}$ jejich zpracování nemá potřebné oprávnění.

\footnotetext{
8 BENNETT MOSES, L. Recurring Dilemmas: The Law's Race to Keep Up with Technological Change. UNSW Law Research Paper. Sydney: UNSW, 2007, vol. 2007, no. 21.

9 BOGUSZAK - ČAPEK - GERLOCH, c. d., s. 156.

10 MELZER, c. d., s. 174.

11 GERLOCH, A. et al. Teorie a praxe tvorby práva. Praha: ASPI, 2008, s. 354-355.

12 MATOUŠOVÁ, M. - HEJLÍK, L. Osobní údaje a jejich ochrana. Praha: ASPI, 2003, s. 10; NOVÁK, D. Zákon o ochraně osobnich údajů a předpisy souvisejicí: komentár̆. Praha: Wolters Kluwer, 2014, s. 222.
} 
Správce či zpracovatel tedy odpovídá za přiměřené zajištění ochrany zpracovávaných osobních údajů, respektive za zajištění jejich bezpečnosti, tedy vlastně za zabránění porušení jejich zabezpečení. Jak naznačuje předchozí věta, jedná se z právně terminologického hlediska o hodnotu či skutečnost, která v současné právní úpravě nemá zcela ustálené označení.

Je však otázkou, zda tato pojmová nejednotnost uvnitř a napříč příslušných právních předpisů z oblasti ochrany osobních údajů značí záměr zákonodárce, tedy je na místě jí věnovat pozornost přri výkladu a aplikaci příslušné právní normy, či zda se jedná o jeden z projevů nedokonalosti zákonodárce, a je tedy na místě odlišnost pojmů překonat výkladem. Pro zodpovězení této otázky je předně nutné analyzovat vývoj institutu a užití předmětných termínů v čase.

\section{PŘEHLED TERMINOLOGIE V RELEVANTNÍCH PRÁVNÍCH PŘEDPISECH}

5.1 ÚMLUVA Č. 108 A ZÁKON Č. 256/1992 SB.

Za první inspirativní podklad české úpravy ochrany osobních údajů lze právem pokládat Úmluvu o ochraně osob se zřetelem na automatizované zpracování osobních dat príijatou Radou Evropy v roce $1981^{13}$ a vstoupivší v platnost ratifikací pěti státy roku 1985. Ačkoliv $\mathrm{k}$ přijetí této mezinárodní smlouvy do českého právního řádu nedošlo před rokem 2001, obsažené principy a pravidla se odrazila v prvním českém zákoně vztahujícím se k problematice ochrany osobních údajů, zákoně č. 256/1992 Sb., o ochraně údajů $\mathrm{v}$ informačních systémech. $Z$ hlediska zde analyzovaných termínů je relevantní článek 7 úmluvy, který se vztahuje v závazném anglickém znění $\mathrm{k}$ data security, resp. v závazném francouzském znění $\mathrm{k}$ sécurité des données. V českém znění přijatém do Sbírky mezinárodních smluv v roce 2001 nese pak článek označení $\boldsymbol{z} \boldsymbol{a b e z}$ pečení údajů. ${ }^{14} \mathrm{~V}$ zákoně č. 256/1992 Sb. je pak namísto termínů bezpečnost či zabezpečení upřednostněno v § 17 písm. i) i § 19 odst. 1 písm. d) spojení zajišstěni ochrany informací. Pojmu zabezpečit je užito pouze ve významu zajistit či obstarat. ${ }^{15}$

\subsection{SMĚRNICE 95/46/ES A ZÁKON Č. 101/2000 SB.}

Za nosnou normu pro etablování ochrany osobních údajů nejen v českém právu, ale např́ič Evropskou unií je pak na místě považovat směrnici 95/46/ES o ochraně osobních údajů. ${ }^{16}$ Tento evropský právní předpis bez prrímé aplikovatelnosti sice

13 COUNCIL OF EUROPE. Convention for the Protection of Individuals with regard to Automatic Processing of Personal Data [online]. 28. 1. 1981 [cit. 29. 4. 2019]. Dostupné na: https://www.coe.int/en/web /conventions/full-list/-/conventions/treaty/108.

14 Sdělení Ministerstva zahraničních věcí o přijetí Úmluvy o ochraně osob se zřetelem na automatizované zpracování osobních dat vyšlo ve Sbírce mezinárodních smluv dne 15. 11. 2001 v částce 52 pod bodem 115.

15 Viz $§ 11$ odst. 1 zákona 256/1992 Sb.

16 Směrnice Evropského parlamentu a Rady 95/46/ES ze dne 24. řijna 1995 o ochraně fyzických osob v souvislosti se zpracováním osobních údajů a o volném pohybu těchto údajů. 
harmonizoval postoj zákonodárců tehdejšího okruhu členských států k problematice ochrany osobních údajů, vyžadoval však transpozici do národního práva.

Proces transpozice směrnice jako takový přestavuje z hlediska právní teorie poměrně složitou proceduru, jelikož dochází k eurokonformnímu přenesení obsahu harmonizovaného evropského předpisu do národního právního řádu, nelze však vyloučit dílčí terminologické či obsahové diskrepance způsobené změnou formulace či rozvedením textu ustanovení na základě diskrece, která je národnímu zákonodárci v rámci systematiky evropského práva v tomto směru poskytnuta. ${ }^{17}$ Pro Českou republiku se směrnice stala právně relevantní $\mathrm{v}$ důsledku aproximace českého práva $\mathrm{v}$ rámci procesu přistoupení k Evropské unii, přičemž důsledkem tohoto procesu byl mimo jiné zákon č. $101 / 2000 \mathrm{Sb}^{18}$

Samotná směrnice nabyla dodatečně závazného znění v českém jazyce, jakožto jazyce nového členského státu. V tomto českém znění směrnice nalézáme plné pojmové spektrum naznačené v předchozí sekci prŕíspěvku. Oddíl VIII a článek 17 směrnice užívají pojmu bezpečnost zpracování (německá verze: Sicherheit der Verarbeitung, anglická verze: Security of processing, francouzská verze: Sécurité des traitements). Obsah pojmu je následně přiblížen v prvním odstavci, kde druhá věta zní: „Tato opatření mají zajistit, s ohledem na stav techniky a na náklady na jejich provedení, přiměřenou úroveň bezpečnosti odpovídající rizikưm vyplývajícím ze zpracování údaju a z povahy údajů, které mají být chráněny. “

Z hlediska výkladu jsou následně relevantní, ač bez srovnatelné právní závaznosti, recitály směrnice. V recitálu 37 je pojednáváno o opatřeních pro zajištění bezpečnosti zpracování, podobně v recitálu 46 je kladen důraz na přijetí př́islušných technických a organizačních opatření s cilem zajistit predevším bezpečnost a tím také zabránit jakémukoli neoprávněnému zpracování. Směrnice oproti tomu až na výjimku recitálu 25 neužívá pojmu zabezpečení. Ten je pak užit jen ve významu technického opatření, jak vyplývá z výňatku: „[...] zásady ochrany se musí odrazit jednak v povinnostech jednotlivců, orgánů veřejné moci, podnikü, agentur nebo jiných subjektio odpovédných za zpracování údajů týkajících se zejména kvality údajů, technického zabezpečení, oznamování okolností, za jakých může být zpracování provedeno [...]“.

Třetím pojmem, který se ve směrnici objevuje a lze pokládat za související, je ochrana. Ta se zde však vzhledem k článku 1 odst. 1 a řadě recitálů obsahově projevuje na abstraktnější právní rovině ochrany práv a svobod dotčených fyzických osob, spíše než ve smyslu souboru opatření na ochranu zpracování osobních údajů. Přesto je v článku 6 odst. 1 písm. b a e pojednáváno o povinnosti členských států stanovit vhodná ochranná opatření, stejně jako je tomu v článku 8 odst. 4 či v recitálu 29.

Pokud pro srovnání nahlédneme do textu zákona č. 101/2000 Sb., který je transpozicí směrnice 95/46/ES českým zákonodárcem, je poměrně překvapující nalézt v označení $\S 13$, který je obsahovou transpozicí výše zmíněného článku 17, pojednání o povinnostech osob při zabezpečení osobních údajü. Také v $\S 6$ a $\S 15$ je opakován pojem zabezpečení osobních údajů, resp. zabezpečení ochrany osobních údajů. Oproti tomu

17 GERLOCH et al., c. d., s. 332.

18 Zákon č. 101/2000 Sb. o ochraně osobních údajů a o změně některých zákonů. 
$\S 44$ odst. 2 písm. h a $\S 45$ odst. 1 písm. h referují nikoliv k zabezpečení osobních údajů, ale k opatřením pro zajištění bezpečnosti zpracováni osobnich údajü.

V zákoně dochází i $k$ pojednání o bezpečnostních opatřeních $\mathrm{v} \S 15$ odst. 1 a znovu pak v $§ 27$ odst. 3 písm. b. Za zmínku pak stojí, že v důvodové zprávě zákona jsou jako subsidiární právní předpisy pro stanovení a aplikaci bezpečnostních opatření ve smyslu $\S 13$ zákona uvedeny předně vyhlášky NBÚ č. 12/1999 Sb. o zajištění technické bezpečnosti utajovaných skutečností a certifikaci technických prostředků; č. 56/1999 Sb. o zajištění bezpečnosti informačních systémů nakládajících s utajovanými skutečnostmi, provádění jejich certifikace a náležitostech certifikátů; a č. 339/1999 Sb. o objektové bezpečnosti.

5.3 SMĚRNICE 2002/58/ES A ZÁKON Č. 127/2005 SB.

Směrnice 95/46/ES však není jediným evropským právním předpisem, který upravuje tuto problematiku. Je zde také speciální úprava pro oblast elektronických komunikací. Tato úprava je významná ze dvou momentů.

Zaprvé jde o mnohem techničtěji koncipovanou normu, jelikož směřuje vůči sektorově omezenému okruhu povinných subjektů. Ochrana sítě a přenášených dat pak nabývá v tomto kontextu širších a složitějších rozměrů, než je pouhá ochrana osobních údajů, jelikož se zde jedná o prvky významné z hlediska kybernetické bezpečnosti. I proto hlavní předpis v této oblasti, směrnice 2002/58/ES, ${ }^{19}$ již v původním znění obsahovala článek 4 týkající se bezpečnosti. V něm je uložena povinnost přijmout vhodná technická a organizační opatření pro zajištění bezpečnosti služeb s ohledem na bezpečnost sítě. Je zde tedy pojednáváno o ochraně před kybernetickým bezpečnostním incidentem, což je pojem, který je v současném českém právním řádu jednoznačně definován a zakotven v $§ 7$ odst. 2 zákona č. 181/2014 Sb., o kybernetické bezpečnosti ${ }^{20}$ jakožto: „, [...] narušení bezpečnosti informaci v informačnich systémech nebo narušení bezpečnosti služeb anebo bezpečnosti a integrity sití elektronických komunikací v důsledku kybernetické bezpečnostní události“.

Zde je pak podstatný druhý moment evropské úpravy elektronických komunikací, a to pozměňovací směrnice 2009/136/ES. ${ }^{21}$ Tato směrnice vnesla do textu směrnice 2002/58/ES malou, avšak z hlediska zde analyzovaného pojmu významnou změnu, skrze inkorporaci nových odstavců 3 až 5 do zmíněného článku 4 týkajícího se bezpečnosti zpracování. Tímto byl do evropského práva vnesen právní instrument ohlašovací povinnosti pro př́ípad narušeni bezpečnosti osobnich údaju․ Směrnice nadto v článku 2 odst. 2 písm. c doplnila konkrétní definici tohoto pojmu. Pro oblast elektronických komunikací tedy platí, že „,narušením bezpečnosti osobnich údajů se rozumí narušení

19 Směrnice Evropského parlamentu a Rady 2002/58/ES ze dne 12. července 2002 o zpracování osobních údajů a ochraně soukromí v odvětví elektronických komunikací.

20 Zákon č. 181/2014 Sb. o kybernetické bezpečnosti a o změně souvisejících zákonů.

21 Směrnice Evropského parlamentu a Rady 2009/136/ES ze dne 25. listopadu 2009, kterou se mění směrnice 2002/22/ES o univerzální službě a právech uživatelů týkajících se sítí a služeb elektronických komunikací, směrnice 2002/58/ES o zpracování osobních údajů a ochraně soukromí v odvětví elektronických komunikací a nařízení (ES) č. 2006/2004 o spolupráci mezi vnitrostátními orgány př́islušnými pro vymáhání dodržování zákonů na ochranu zájmů spotřebitele. 
bezpečnosti, které vede $k$ náhodnému nebo protiprávnímu zničení, ztrátě, změně či neoprávněnému vyzrazení nebo zpřistupnění osobnich údajů přenášených, uchovávaných nebo jinak zpracovávaných v souvislosti s poskytováním veřejně dostupné služby elektronických komunikací ve Společenstvi". Tato terminologie je ve zmíněném segmentu evropského práva vysoce konzistentní, jak potvrzuje i navazující nařízení 611/2013 o opatřeních vztahujících se na oznámení o narušení bezpečnosti osobních údajů. ${ }^{22}$

Pokud česká verze užívá pojmů bezpečnost zpracování a narušení bezpečnosti osobních údajů, je vhodné upozornit na dalších jazykové verze, především na německou, která uživá pojmy Sicherheit der Verarbeitung a Verletzung des Schutzes personenbezogener Daten, anglickou s pojmy Security of processing a personal data breach, či francouzská s pojmy Sécurité du traitement a violation de données à caractère personnel. Je zde tedy možné ve všech verzích nalézat konzistenci se směrnicí 95/46/ES ve směru užití českého pojmu bezpečnost zpracování.

Srovnatelnou konzistenci však nenalézáme v transpozici těchto právních norem provedené českým zákonodárcem. Směrnice 2002/58/ES byla do českého práva transponována v podobě, v mezidobí silně novelizovaného, zákona č. 127/2005 Sb., o elektronických komunikacích. ${ }^{23} \mathrm{Z}$ hlediska řešeného pojmu je však př́slušný předpis temporálně vysoce konzistentní, v $\S 88$ zde nalezneme namísto bezpečnosti zabezpečení ochrany osobních, provozních a lokalizačních údajů a di̊věrnosti komunikací. Pokud pak nahlédneme do definic v $\S 2$, směrnicí vymezené narušení bezpečnosti osobních údajů český zákonodárce pod písm. y transponoval jako porušení ochrany osobních údajư, které je ovšem vymezeno jako ,porušení bezpečnosti, které vede k neoprávněnému př́stupu nebo k neoprávněné nebo nahodilé změně, zničení, vyzrazení či ztrátě osobnich údajů zpracovávaných v souvislosti s poskytováním veřejně dostupné služby elektronických komunikaci".

\subsection{OBECNÉ NAŘÍZENÍ 2016/679, SMĚRNICE 2016/680 A ZÁKON Č. 110/2019 SB.}

Třetím a v současné době nejvýznamnějším souborem právních norem týkajících se diskutované problematiky je od 25. května 2018 př́mo účinné obecné nařízení 2016/679, ${ }^{24}$ které nahradilo právní rámec směrnice 95/46 ES, a paralelně přijatá směrnice $2016 / 680 .^{25}$

Na rozdíl od výše představené konzistentní terminologie na evropské úrovni v podobě směrnice 95/46/ES a směrnice 2002/58/ES užívá obecné nařízení 2016/679 v české verzi pro článek 32 označení zabezpečení zpracování. Články 33 a 34 tudíž upravují ohlašování a oznamování př́ípadů porušení zabezpečení osobních údajů a v článku 4

22 Nařízení Komise (EU) č. 611/2013 ze dne 24. června 2013 o opatřeních vztahujících se na oznámení o narušení bezpečnosti osobních údajů podle směrnice Evropského parlamentu a Rady 2002/58/ES o soukromí a elektronických komunikacích.

${ }^{23}$ Zákon č. 127/2005 Sb. o elektronických komunikacích a o změně některých souvisejících zákonů.

24 Nařízení Evropského parlamentu a Rady (EU) 2016/679 ze dne 27. dubna 2016 o ochraně fyzických osob v souvislosti se zpracováním osobních údajů a o volném pohybu těchto údajů a o zrušení směrnice 95/46/ES.

25 Směrnice Evropského parlamentu a Rady (EU) 2016/680 ze dne 27. dubna 2016 o ochraně fyzických osob v souvislosti se zpracováním osobních údajů př́slušnými orgány za účelem prevence, vyšetřování, odhalování či stíhání trestných činů nebo výkonu trestů, o volném pohybu těchto údajů a o zrušení rámcového rozhodnutí Rady 2008/977/SVV. 
bodu 12 je porušení zabezpečení osobních údaju definováno jako ,porušení zabezpečení, které vede k náhodnému nebo protiprávnímu zničení, ztrátě, změně nebo neoprávněnému poskytnutí nebo zpřistupnění přenášených, uložených nebo jinak zpracovávaných osobnich údajü“".

Pokud však nahlédneme do cizojazyčných verzí nařizení, nalézáme stále v německé verzi pojmy Sicherheit der Verarbeitung a Verletzung des Schutzes personenbezogener Daten, v anglické verzi pojmy Security of processing a personal data breach, a ve francouzské verzi pojmy Sécurité du traitement a violation de données à caractère personnel. Ve všech třech zmíněných cizojazyčných verzích je tedy na rozdíl od české verze plná konzistence s výše popsanou evropskou terminologií směrnice 95/46/ES a směrnice $2002 / 58 / \mathrm{ES}$.

Při snaze o rozklíčování původu této pojmové proměny v českém znění obecného nařízení je vhodné přihlédnout ke zněním v rámci dlouhého a komplikovaného legislativního procesu přijímání nařízení. Pokud nahlédneme do českého znění původního návrhu obecného nařízení předloženého Evropskou komisí a schváleného Evropským parlamentem v roce 2014, zjistíme, že zde bylo předvídatelně užito pro výše popsané články pojmu narušení bezpečnosti osobních údajů. ${ }^{26}$ Je zde tedy soulad s terminologií novelizované směrnice 2002/58/ES, která byla výslovně uvedena za podklad instrumentu přeneseného do obecného nařizení. ${ }^{27}$ I ve verzi obecného nařízení přijaté Radou v roce 2015 sice dochází k modifikaci textu ustanovení, stále je však pro celý Oddíl 2 i článek 30 (budoucí článek 32) voleno označení bezpečnost zpracování a článek 31 (budoucí článek 33) se váže k porušení ochrany osobních údajů. ${ }^{28} \mathrm{Ci}$ zojazyčné verze předmětných článků přitom zůstávají pojmově konzistentní po celý legislativní proces.

Z uvedeného je tedy zjevné, že ke změně české terminologie pro tuto část obecného nařízení dochází až v pozdní části legislativního procesu v rámci trialogu Evropské komise, Evropského parlamentu a Rady, přičemž nic nenaznačuje tomu, že by změna pojmů reflektovala změnu v obsahu daných pojmů či předmětného právního instrumentu oproti směrnici 95/46/ES a směrnici 2002/58/ES.

Ostatně nekonzistence terminologie české verze se projevuje i ve vlastním obsahu článku 32, který přestože pojednává o zabezpečení zpracování, obsahuje v odst. 1 písm. d požadavek na zajištění odpovídající úrovně zabezpečení včetně ,procesu pra-

26 EVROPSKÝ PARLAMENT. Legislativni usneseni Evropského parlamentu ze dne 12. března 2014 o návrhu nařizeni Evropského parlamentu a Rady o ochraně fyzických osob v souvislosti se zpracováváním osobnich údajů a o volném pohybu těchto údajů (obecné nařizeni o ochraně údajü) (COM(2012)0011C7-0025/2012-2012/0011(COD)) [online]. 12.3. 2014 [cit. 29. 4. 2019]. Dostupné na: https://www.europarl .europa.eu/sides/getDoc.do?pubRef=-//EP//NONSGML+TA+P7-TA-2014-0212+0+DOC+PDF+V0//CS.

27 EVROPSKÁ KOMISE. Návrh nařizeni Evropského parlamentu a Rady o ochraně fyzických osob v souvislosti se zpracováváním osobnich údajů a o volném pohybu těchto údaju (obecné nařizeni o ochraně údaju) COM(2012) 11 final [online]. 25. 1. 2012 [cit. 29. 4. 2019]. Dostupné na: https://eur-lex.europa.eu /legal-content/cs/TXT/PDF/?uri=CELEX:52012PC0011\&from=EN, s. 10.

28 RADA EU. Návrh nařizení Evropského parlamentu a Rady o ochraně fyzických osob v souvislosti se zpracováním osobnich údaju a o volném pohybu těchto údajů (obecné nařizení o ochrané údajů) - príprava obecného prístupu 2012/0011 (COD) [online]. 11. 6. 2015 [cit. 29. 4. 2019]. Dostupné na: http://data .consilium.europa.eu/doc/document/ST-9565-2015-INIT/cs/pdf. 
videlného testování, posuzování a hodnoceni účinnosti zavedených technických a organizačnich opatřeni pro zajištění bezpečnosti zpracováni". Odst. 2 pak pokračuje v této terminologické odchylce a stanoví: „Při posuzování vhodné úrovně bezpečnosti se zohledni zejména rizika [...].“ Termín je také užit v článku 35 týkajícím se posouzení vlivu na ochranu osobních údajů, kde je zmínka o bezpečnostních opatřeních a mechanismech k zajišstění ochrany osobních údajů a o bezpečnosti operací zpracování.

Nejvýznamnější projev vnitřní rozporuplnosti terminologie obecného nařízení 2016/679 je pak obsažen v článku 40 odst. 2 písm. h, kde je namísto o zabezpečení zpracování na článek 32 odkazováno textem: „,...] opatřeni k zajištěni bezpečnosti zpracováni podle článku 32." Jinak je pojem bezpečnosti zpracování v obecném nařízení 2016/679 zmíněn pouze $\mathrm{v}$ recitálu 81.

Pokud nahlédneme do směrnice 2016/680, přijaté společně s obecným nařízením 2016/679, nalézáme v zásadě shodnou terminologii jako v nařízení. Článek 3 bod 11 definuje souladně s nařízením 2016/679 porušení zabezpečení osobnich údajů. Pojmů zabezpečení osobnich údaju či zabezpečení zpracování je pak užito v článku 4 odst. 1 písm. f, článku 25 odst. 2, článku 29, 30, 31, či článku 51 odst. 1 písm. d a e. Pouze recitál 28 obsahuje v jednom souvětí oba pojmy, když uvádí: „Aby byla zachována bezpečnost zpracování a zabránilo se zpracování v rozporu s touto směrnicí, měly by být osobni údaje zpracovávány zpưsobem, který zajistí náležitou úroveñ zabezpečení a mlčenlivosti $[\ldots]$ “ Z Zyývající recitály konzistentně operují s pojmem zabezpečení zpracování.

Dne 24. dubna 2019 nabyl účinnosti zákon č. 110/2019 Sb., o zpracování osobních údajů, který nahrazuje výše zmíněný zákon č. 101/2000 Sb. a zajišttuje adaptaci národní právní úpravy v důsledku prímé účinnosti obecného nařízení 2016/679 a transpozici směrnice 2016/680 (společně se změnovým zákonem č. 111/2019 Sb., kterým se mění některé zákony v souvislosti s prrijetím zákona o zpracování osobních údajů). Tento zákon v § 12 užívá termínu porušení zabezpečení osobních údajů. Obdobně v $§ 19$ odst. 4 , § 32 odst. 4 písm. i, § 34 odst. 4 písm. d, § 36 odst. 3 , §§ 40, 41, 42, 46, § 59 odst. 1 a $\S 63$ zákona.

Avšak v $§ 16$ o zpracování osobních údajů za účelem vědeckého nebo historického výzkumu nebo pro statistické účely odst. 1 písm. j poměrně překvapivě pojednává o posuzování a hodnocení účinnosti zavedených technických a organizačních opatření pro zajištění bezpečnosti zpracování. Stejně tak v $\S 44$ zákon uvádí „[... [ záruky zpracovatele o príietí a dodržování technických a organizačnich opatření k zajištěni bezpečnosti a ochrany osobnich údajü“. Nakonec pak i § 47 zmiňuje ,[...] zachovávat mlčenlivost o osobnich údajich a o organizačnich a technických opatřeních, jejichž zveřejnění by ohrozilo bezpečnost osobnich údajü“.

\section{DISKUSE}

Předcházející kapitola př́spěvku analyzovala terminologii relevantních právních předpisů týkajících se problematiky, která je v anglické terminologii označována v evropském právu jako personal data breach. Jak bylo výše poukázáno, např́ic 
evropskými předpisy lze vnímat konzistenci užitých termínů k této problematice jak v anglickém jazyce, tak v jazykových verzích německých a francouzských.

\subsection{K OBSAHOVÉ KONTINUITĚ POJMU゚ V ČESKÉM PRÁVU OCHRANY OSOBNÍCH ÚDAJŮ}

Při studiu českých verzí těchto předpisů je však zjevná odlišnost terminologie u nejnovějších předpisů, tedy u obecného nařízení 2016/679 a směrnice 2016/680, která byla přenesena do nového zákona č. 110/2019 Sb. Dosud konzistentně užívané termíny bezpečnost zpracování a narušení bezpečnosti osobních údaju jsou zde v zásadě napříč předpisem nahrazeny termíny zabezpečení zpracování a porušení zabezpečení osobních údajü.

Současně je v tomto směru navázáno na terminologii zákona č. 101/2000 Sb., který představoval transpozici směrnice 95/46/ES. Český zákonodárce se již zde odchýlil od zmíněné evropské terminologie a zavedl pojem zabezpečení zpracování. V tomto směru lze tedy vnímat jistou konzistenci terminologie české právní úpravy.

S tímto argumentem konzistence se však nelze ve světle eurokonformního výkladu spokojit. Na jeho metodologickou rovnocennost s ústavněkonformním výkladem upozorňuje Melzer $^{29}$ s odkazem na rozhodnutí velkého senátu Soudního dvora Evropské unie (tehdy stále ještě Evropského soudního dvora) ve věci Bernhard Pfeiffer a další, spojené věci C-397/01 až C-403/01 ze dne 5. rríjna 2004. ${ }^{30}$ Bod 113 rozhodnutí prrímo uvádí: „Vnitrostátní soud je tak při použití vnitrostátního práva a zejména ustanovení právní úpravy specificky přijaté za účelem provedení požadavků směrnice povinen vykládat vnitrostátní právo v co možná největším rozsahu ve světle znění a účelu přislušné směrnice, aby tak dosáhl výsledku jí zamýšleného, a dosáhl tak souladu s třetím pododstavcem článku 249 ES (viz v tomto smyslu zejména výše uvedené rozsudky Von Colson a Kamann, bod 26; Marleasing, bod 8, a Faccini Dori, bod 26; viz rovněž rozsudky ze dne 23. února 1999, BMW, C63/97, Recueil, s. 1905, bod 22; ze dne 27. června 2000, Océano Grupo Editorial a Salvat Editores, C240/98 až C244/98, Recueil, s. I4941, bod 30, a ze dne 23. ř́jna 2003, AdidasSalomon a Adidas Benelux, C408/01, Recueil, s. I12537, bod 21).“

Mnohojazyčnost evropského práva je obecně unikátní situací, která vytváří řadu specifických výzev a problémů. Je ovšem nežádoucí stav, aby studium odlišných jazykových verzí vedlo k rozdílným výkladovým závěrům. ${ }^{31}$

Pro argument, že se jedná o nevhodný terminologický odklon, nikoliv o účelné odlišení institutů, hovoří též podrobnější studium dostupné odborné a komentářové literatury vážící se k zákonu č. 101/2000 Sb.

29 MELZER, c. d., s. 178.

30 Rozsudek Soudního dvora (velkého senátu) ze dne 5. ř́jna 2004 ve spojených věcech Bernhard Pfeiffer (C-397/01), Wilhelm Roith (C-398/01), Albert Süß (C-399/01), Michael Winter (C-400/01), Klaus Nestvogel (C-401/01), Roswitha Zeller (C-402/01) a Matthias Döbele (C-403/01) proti Deutsches Rotes Kreuz, Kreisverband Waldshut $\mathrm{eV}$.

31 KŘEPELKA, F. Mnohojazyčnost Evropské unie a jeji di̊sledky pro českou právní praxi. Brno: Masarykova Univerzita, 2007, s. 67. 
Komentář k zákonu z pera Kučerové, Bartíka, Peci, Neuwirtha a Nejedlého z roku 2003 při diskusi klíčového $\S 13$ zákona již v úvodním odstavci takto jednoznačně odkazuje na terminologii směrnice: „Tímto ustanovením je stanovena obecná povinnost správců a zpracovatelù osobních údajů tyto údaje chránit. Jedná se o dalši ze základních povinností (viz komentár $k \S 5$ ), jejímž obsahem je povinnost ze strany správců a zpracovatelì zajistit tzv. , bezpečnost dat ' [...]. "32 Autoři následně užívají terminologii zákona při diskusi „výčtu situací, na které musí reagovat zabezpečení osobních údajü“ 33 a „,naplnění povinností stanovených k zabezpečení (ochraně) osobních údajü“. ${ }^{34}$

Prakticky koncipovaná monografie Matoušové a Hejlika Osobní údaje a jejich ochrana, taktéž z roku 2003, v teoretickém úvodu vykládá rovinu zabezpečení osobních údajů před únikem a zneužitím jako pojímající nejen informační bezpečnost, ale též ,[...] formalistický mikrosvět byrokratických a technokratických omezení ochranárù a strážců různých tajemství majetku a připadně jinak vymezovaných hodnot" ${ }^{35} \mathrm{~V}$ kapitole týkající se výkladu povinnosti přijmout bezpečnostní opatření dle $\S 13$ zákona však autoři zdůrazňují př́ípadnost pojmu bezpečnost nejen s odkazem na recitál 46 směrnice, ${ }^{36}$ ale též při argumentaci ve prospěch podpůrného využití právních úprav pro bezpečnostní opatření pro jiné formy bezpečnosti. ${ }^{37}$

To, že se pojem zabezpečení na úkor pojmu bezpečnost v českém akademickém diskursu pevně neustálil, pak dokazují monografie vydané s výrazným časovým odstupem od účinnosti zákona č. 101/2000 Sb.

V komentáŕi k zákonu č. 101/2000 Sb. Bartika a Janečkové z roku 2010 začíná výklad k $\$ 13$ odst. 1 větou: „Tímto ustanovením je určena obecná povinnost správců a zpracovatelì osobních údajů chránit osobní údaje. Jedná se o dalši ze základních povinností, jejímž obsahem je povinnost zajistit tzv. ,bezpečnost zpracovávaných osobních údajů ' [...]. "38 Lze také citovat $\mathrm{z}$ úvodu komentáře pro odst. 3 daného paragrafu: „S ohledem na velmi obecnou formulaci povinnosti zajistit bezpečnost osobních údajü, byl Úr̆ad od samého počátku své existence žádán o vymezení základních bezpečnostních podmínek nějakým zvláštním opatřením Úřadu nebo právním predpisem."39

U monografie Matese, Janečkové a Bartika z roku 2012 lze pro zajímavost zmínit, že ačkoliv výše zmíněné české znění Úmluvy č. 108 publikované ve Sbírce mezinárodních smluv prrekládá článek 7 jako Zabezpečení údajů, autoři na něj odkazují za užití sousloví Zásada bezpečnosti. ${ }^{40}$

Komentář k zákonu č. 101/2000 Sb. autorského kolektivu pod vedením Kučerové z roku 2012 v poznámkách $\mathrm{k} \S 13$ zákona silně inklinuje k preferování pojmu bezpečnost před pojmem zabezpečení. Příkladem následující krátké úryvky: ,[...] správce je povinen zvolit si pouze takové zpracovatele, kteři garantují potřebnou míru bez-

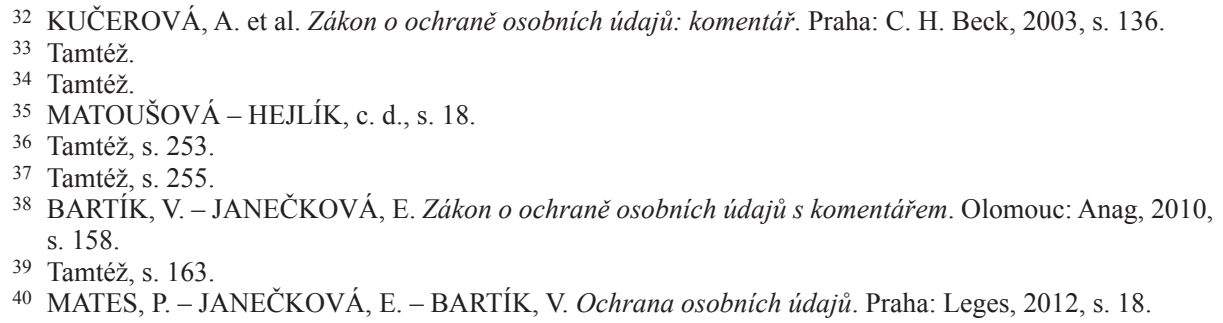

38 BARTÍK, V. - JANEČKOVÁ, E. Zákon o ochraně osobních údajů s komentárem. Olomouc: Anag, 2010, s. 158 . 
pečnosti zpracováni“; $; 1$ „Správce osobních údajů uzavřením takové smlouvy zajištuje, že také zpracováni prováděné zpracovatelem osobnich údaju bude probihat v souladu s požadavky na bezpečnost zpracovávaných dat",42 „[...] \& 13 OchOsú nemůže obsahovat detailní nebo přmo taxativni výčet opatření potřebných $k$ zajištěni bezpečnosti zpracovávaných dat“;43 „Dalši kategorii opatřeni ve smyslu § 13 odst. 1 OchOsÚ jsou vnitřni organizačni opatření, tj. závazné interni normy či pokyny stanovíci odpovědnost konkrétnich osob za bezpečnost zpracovávaných osobnich údajů [...]“,44 „Rizika pro bezpečnost osobních údajů vznikaji také v souvislosti s využiváním elektronické pošty [...]“;45, „Kromě povinnosti podniknout konkrétní kroky k zajištěni bezpečnosti zpracovávaných osobnich údaju může správce postupem podle § 6 OchOsú pověrit zpracovatele také zpracováním dokumentace opatření [...] ;446 či „Podle citovaných sankčních ustanovení je totiž v rozporu se zákonem o ochraně osobních údaju pouze nepřijetí či neprovedeni opatření pro zajištěni bezpečnosti zpracováni osobnich údajü.“47

Novák ve svém podrobném komentáři k zákonu č. 101/2000 Sb. z roku 2014 taktéž uvádí svůj rozbor $\S 13 \mathrm{v}$ podobném duchu: „Problematiku bezpečnosti osobních údaju upravuje článek 17 směrnice 95/46/ES, konkretizujíci jeden ze základních principů ochrany osobnich údajü.“48 $\mathrm{Na}$ to následně navazuje jak slovy: „,[Ustanovení § 13 odst. 1] Nedefinuje ani jednotlivé prostředky zajištujicí bezpečnost osobnich údajü; bliže se k této otázce vyjadřuji odst. 3 a 4 “;,49 tak komentářem: „Byt' v 13 odst. 1 zák. o ochraně os. údajů nediferencuje mezi jednotlivými kategoriemi správců údajů, je nabiledni, že pojem bezpečnosti bude mit rozdilný obsah v závislosti na rizicich, kterým správce údajů, resp. subjekty údajů, čeli.“"50 Přestože se pak Novák při diskuzi konkrétních rozhodnutí Úřadu pro ochranu osobních údajů přidržuje terminologie zákona, ${ }^{51}$ svou inklinaci k užití pojmu bezpečnost dává najevo v následujících pasážích komentáře, kde uvádí např.: „Lze zdưraznit, že porušení § 13 odst. 1 zakládá též delikt ohrožovací, který je dokonán již tehdy, pokud je bezpečnost osobnich údajů jednáním správce údaju ohrožena“; 52 „Tím spišse správce údajů není oprávněn činit odpovědným za bezpečnost subjekt údajü, vystupujicí kupř. v pozici př́jemce služby“;53 či: „Citované ustanovení ukládá správci osobnich údajů povinnost přijmout technická i organizační opatřeni k zajištěni bezpečnosti zpracovávaných osobnich údajů, přičemž porušením této povinnosti je již situace, kdy vznikne riziko neoprávněného př́stupu k osobním údajům."

${ }^{41}$ KUČEROVÁ, A. et al. Zákon o ochraně osobnich údajů: komentár̆. Praha: C. H. Beck, 2012, s. 228.

42 Tamtéž, s. 228.

43 Tamtéž, s. 229.

44 Tamtéž, s. 231.

45 Tamtéž, s. 233.

46 Tamtéž, s. 235.

47 Tamtéž, s. 236.

48 NOVÁK, D. Zákon o ochraně osobnich údajů a předpisy souvisejicí: komentářr. Praha: Wolters Kluwer, 2014, s. 222.

49 Tamtéž.

50 Tamtéž, s. 223.

51 Tamtéž, s. 225-226.

52 Tamtéž, s. 228.

53 Tamtéž, s. 230.

54 Tamtéž, s. 232. 
Lze tedy uzavřít, že při výkladu obsahu termínů užitých zákonem č. 101/2000 Sb. bylo přes jejich terminologický odklon stále na místě co možná nejvíce vycházet z jejich zachycení ve směrnici 95/46/ES. S ohledem na proklamovanou kontinuitu obsahu pojmů, i absenci změn v jiných jazykových verzích, lze pak dojít k závěru, že pojmy zabezpečení a bezpečnost (zpracování) osobních údajů, jakož i narušení bezpečnosti a porušení zabezpečení by měly být vnímány co do obsahu a právní teorie za totožné a provázané.

\subsection{K TERMINOLOGICKÉ PREFERENCI POJMU BEZPEČNOST}

Upřednostnění pojmu zabezpečení před pojem bezpečnost pro české právo ochrany osobních údajů při současném přímém dopadu obecného nařízení je tudíž zřetelně zavádějící. Ostatně výše nastíněný vývoj jazykových verzí v legislativním procesu přijetí obecného nařízení i zmíněné vnitřní nekonzistence, jako odkaz ve článku 40 odst. 2 písm. h obecného nařízení, silně indikují, že zavedení pojmu zabezpečení na úkor pojmu bezpečnost do české jazykové verze obecného nařízení je důsledkem nedopatření překladatele, nikoliv záměrem zákonodárce.

Za přijetí této premisy je však na místě položit si otázku, jaký má tento objevený terminologický nedostatek význam, tedy zda lze obecně nalézat obsahový rozdíl mezi pojmy bezpečnost a zabezpečení. Proto je na místě nahlédnout blíže na význam užití těchto termínů v právu i v souvisejících oborech relevantních pro problematiku zajištění ochrany osobních údajů v moderní společnosti.

Pojem bezpečnost má zakořeněný a konzistentně aplikovaný význam v úzké souvislosti s technickými, ale i společenskovědními rovinami zde diskutovaného problému. Významným oborem jsou v tomto směru bezpečnostní studia, která řeší mezinárodní, společenské a politické roviny problematiky bezpečnostních hrozeb a bezpečnostních opatření. ${ }^{55}$ Bezpečnost $\mathrm{v}$ tomto kontextu nabývá řadu významů, které se mohou dotýkat ochrany osobních údajů, ale také ji výrazně přesahovat. ${ }^{56} \mathrm{~V}$ právní terminologii je pojem bezpečnosti etablován především v blízkém překryvu pro oblast kybernetické bezpečnosti. Kybernetická bezpečnost představuje souhrnný zastřešující koncept pro soubor právních, organizačních, technických a dalších prostředků a opatření, které směřjí k zajištění důvěrnosti, integrity a dostupnosti dat, sítí a systémů $\mathrm{v}$ rámci kyberprostoru. ${ }^{57}$ Nepominutelnou rovinou je pak také technická perspektiva zajištění bezpečnosti ICT sítí a systémů. Pro závaznou terminologii je v tomto ohledu na místě upozornit na přijaté technické normy ČSN, především normu ČSN ISO/IEC 27000 Systémy řizení bezpečnosti informaci - Přehled a slovnik, ${ }^{58}$ či pak prríkladem normu ČSN ISO/IEC 27017 Soubor postupů pro opatření bezpečnosti informací pro cloudové služby zalo-

55 Viz např. Charakteristika oboru Bezpečnostní studia FSV MUNI [online]. [cit. 17. 3. 2019]. Dostupné na: https://fsv.cuni.cz/uchazeci/magisterske-studium/bezpecnostni-studia.

56 Viz např. studijní materiál Bezpečnost (Miroslav Mareš) [online]. [cit. 17. 3. 2019]. Dostupné na: https:// is.mendelu.cz/eknihovna/opory/zobraz_cast.pl?cast=69511.

57 Srov. JIRÁSEK, P. - NOVÁK, L. - POŽÁR, J. Výkladový slovník Kybernetické bezpečnosti [online]. Brno: Národní centrum kybernetické bezpečnosti, 2015 [cit. 10. 1. 2019]. Dostupné na: https://www .govcert.cz/download/aktuality/container-nodeid-665/slovnikkb-cz-en-1505.pdf, s. 69.

58 Náhled normy dostupný na: https://shop.normy.biz/detail/501452\#nahled [cit. 17. 3. 2019]. 
žený na ISO/IEC 27002 (v anglickém znění: Code of practice for information security controls based on ISO/IEC 27002 for cloud services). ${ }^{59}$

Pojem zabezpečení oproti tomu nemá srovnatelnou terminologickou bázi, která by odůvodňovala jeho záměnu s pojmem bezpečnost. Nejedná se ani o pojem široce či běžně užívaný, jelikož jde $\mathrm{v}$ převážné mírre o zpodstatněné sloveso zabezpečit, které se významově blíží slovesům zajistit či zaručit. ${ }^{60}$ Tomu odpovídá i v podstatě jediný běžný význam slova $\mathrm{v}$ právní terminologii, tedy problematika sociálního zabezpečení, která vytváří rámec záruk a podpory pro zajištění základních potřeb občanů v rámci společenské solidarity. Ovšem i v teorii práva sociálního zabezpečení zaznívají hlasy, které upozorňují na původ termínu v nepřesném překladu a větši přiléhavosti pojmu sociální bezpečnost. ${ }^{61}$ Jiní autoři doplňují, že termín zabezpečení odpovídal dynamické činnosti přerozdělování důchodů $\mathrm{v}$ komunistickém pojetí, zatímco pojem bezpečnost je bliže současnému stavovému zajištění odpovídajících práv v demokratické společnosti. ${ }^{62}$ Vzhledem $\mathrm{k}$ tomuto lze pojem zabezpečení $\mathrm{v}$ právní terminologii ochrany osobních údajů považovat za nepř́ípadný a neodpovídající obsahu, ke kterému je v českém znění obecného nařízení 2016/679 a směrnice 2016/680 užit.

$\mathrm{Z}$ tohoto důvodu lze $\mathrm{v}$ užití pojmu zabezpečení vnímat $\mathrm{z}$ hlediska právní teorie nevhodný terminologický odklon, který je na újmu českému právu ochrany osobních údajů. Nebezpečí z toho plynoucí je především zbytečné oddálení právní a technické roviny této problematiky, jelikož, jak bylo zmíněno výše, české technické normy pro tuto oblast pracují s pojmy bezpečnost a narušení bezpečnosti. V situaci, kdy je ze strany všech úrovní recipientů právního rámce ochrany osobních údajů voláno po vy̌šší srozumitelnosti a provázanosti s konkrétními technickými a organizačními požadavky, je pak tento jev značně nešt'astný.

\section{ZÁVĚR}

Jádrem př́spěvku byla analýza terminologie národních i evropských právních předpisů ochrany osobních údajů ve vztahu k problematice narušení bezpečnosti, resp. porušení zabezpečení zpracování. Je představen př́stup k pojmu v relevantních normách zahrnujících Úmluvu č. 108 Rady Evropy, zákon č. 256/1992 Sb., směrnici 95/46/ES, zákon č. 101/2000 Sb., směrnici 2002/58/ES novelizovanou směrnicí 2009/136/ES, zákon č. 127/2005 Sb., obecné nařízení 2016/679, směrnici 2016/680 i nedávno přijatý zákon č. 110/2019 Sb. Hlavním poznatkem je odklon pojmů užitých ve finální české jazykové verzi obecného nařízení 2016/679 od konzistentní terminologie předcházejících evropských právních předpisů bez zjevného důvodu či odrazu v jiných jazykových verzích obecného nařízení.

59 Náhled normy dostupný na: http://csnonlinefirmy.unmz.cz/html_nahledy/36/502319/502319_nahled.htm [cit. 17. 3. 2019].

60 Srovnání viz ABZ slovník českých synonym [online]. 2019 [cit. 17. 3. 2019]. Dostupné na: http://www .slovnik-synonym.cz/web.php/slovo/zabezpecit.

61 GALVAS, M. - GREGOROVÁ, Z. Sociální zabezpečení. Brno: Masarykova univerzita, Právnická fakulta, 2000, s. 22.

62 TOMEŠ, I. et al. Právo sociálního zabezpečení. Praha: Všehrd, 1993, s. 11. 
V rámci diskuse jsou představeny dva závěry, které má př́spěvek za cíl podpořit v rámci akademického diskurzu ve snaze o překonání tohoto nedostatku účinné právní úpravy.

Zaprvé je na základě rozboru terminologie užívané českou odbornou veřejností ke zmíněné problematice i vzhledem k požadavku na jednotný eurokonformní výklad dovozeno, že předmětná normativní úprava obecného nařízení 2016/679 a směrnice 2016/680 plně navazuje na úpravu dle směrnici 95/46/ES a směrnici 2002/58/ES a není zde na místě nalézat obsahové odlišnosti v důsledku odlišnosti užitých pojmů.

Zadruhé je argumentováno, že pojmy zabezpečení zpracování a porušení zabezpečení (zpracování) osobních údajů jsou z hlediska teorie nepř́ípadné a v zájmu zdůraznění provázanosti jak eurokonformní, tak mezioborové, je na místě upřednostňovat v rámci odborného diskurzu pojmů bezpečnost zpracování, resp. narušení/porušení bezpečnosti (zpracování) osobních údajů.

Závěr př́spěvku nelze jistě přeceňovat co do významu, především ve srovnání s klíčovými obsahovými změnami, které přinesla reforma ochrany osobních údajů, jako je napríklad již vlastní zakotvení obecné povinnosti ohlašování a oznamování porušení bezpečnosti (zabezpečení) osobních údajů vůči všem správcům osobních údajů. Přesto je na místě upozornit na tuto neopodstatněnou nekonzistenci v české verzi daného evropského předpisu a prosazovat reflektování vhodného pojmosloví přinejmenším v rovině odborného diskurzu.

Mgr. Ing. František Kasl

Právnická fakulta Masarykovy univerzity

frantisek.kasl@mail.muni.cz 